\title{
QUALITY OF LIFE AT WORK IN A PUBLIC MOTHER-CHILD CENTER IN SOUTHEASTERN BRAZIL
}

Lucas Alves de Oliveira Lima 1, Elisama Angélica de Carvalho Fonseca 2, Paulo Lourenço Domingues Junior ${ }^{3}{ }^{凶}$. Karen Martins Peixoto ${ }^{4}$, Caio Barros Gomes da Silva ${ }^{5}$

1,5 Graduating in Administration from the Federal Rural University of Rio de Janeiro (UFRRJ), Brazil

2, 4 Undergraduate student in Administration at the Federal Rural University of Rio de Janeiro (UFRRJ), Brazil

${ }^{3} \mathrm{PhD}$ in Sociology from the University of São Paulo and associate professor at the Federal Rural University of Rio de Janeiro (UFRRJ), Brazil

DOI: https://doi.org/10.29121/granthaalayah.v8.i9.2020.1242

Article Type: Research Article

Article Citation: Lucas Alves de Oliveira Lima, Elisama Angélica de Carvalho Fonseca, Paulo Lourenço Domingues Junior. Karen Martins Peixoto, and Caio Barros Gomes da Silva. (2020). QUALITY OF LIFE AT WORK IN A PUBLIC MOTHERCHILD CENTER IN SOUTHEASTERN BRAZIL. International Journal of Research -GRANTHAALAYAH, 8(9), 312-317.

https://doi.org/10.29121/granthaa layah.v8.19.2020.1242

Received Date: 20 August 2020

Accepted Date: 30 September 2020

Keywords:

Quality of Life at Work (QLW)

Satisfaction at Work

Health Professionals

\section{ABSTRACT}

The general objective of this research was to analyze the perceptions of public employees of a Mother and Child Center in the municipality of Paraíba do Sul/RJ about what is Quality of Life at Work (QLW) and the main positive and negative factors that affect quality of life in the unit. This is an exploratory survey of qualitative approach, where techniques of observation and structured interview were used through a questionnaire answered by ten employees. Through the results, it was possible to verify that the main perceptions about QLW are linked to good interpersonal relationships and well-being in the service. Regarding the positive aspects of the work, good relationships with colleagues were highlighted, while the negative elements were the lack of materials to perform the tasks and the high workload.

\section{INTRODUCTION}

Contemporary organizations are today in a process of profound political, economic and cultural transformation in search of a higher level of productivity in conciliation with the well-being of employees. Nowadays, society is characterized by globalization, the main characteristics being the rapid and constant changes, which directly impact the way companies are managed (SAMPAIO, 2012).

(C) 2020 The Author(s). This is an open access article distributed under the terms of the Creative Commons Attribution License, which permits unrestricted use, distribution, and reproduction in any medium, provided the original author and source are credited. 
In this context, the theme Quality of Life at Work (QLW) has gained prominence in the global scenario, thus giving rise to a debate around the valuation of human capital and well-being at work. QLW has several definitions and, for Albuquerque (2002), the term is linked to the humanization of the employee at work, in which it involves managerial strategies that aim to deteriorate the mechanistic vision at work.

According to Sampaio (2012), workers are suffering more and more health impacts due to performance charging and the perception of acceleration of time for work activities. In this scenario, public health professionals are the most susceptible to occupational illnesses because they are working in a job characterized by confronting illnesses with the prominence of chemical, physical, psychological and biological risks.

In Brazil, most health care professionals deal with a precarious work routine with a long working day, inadequate infrastructure, lack of materials to perform tasks and/or incomprehensible patients. Based on these aspects, cases of dissatisfaction, stress, Burnout Syndrome and Dort are constant among such employees, which end up contributing to affect the quality of life at work. Such diseases cause physical and/or psychological implications to individuals, thus affecting work performance, interpersonal relationships and productivity (MACHADO et. al, 2014).

Based on these aspects, this research aimed at analyzing what perceptions the public employees of a Paraíba do Sul Maternal and Child Center have regarding Quality of Life at Work (QLW). The Center in question is located in the city of Paraíba do Sul, in the interior of Rio de Janeiro in the Southeast of Brazil and has an estimated population of 45 thousand (IBGE, 2018). In the unit, several services are offered to children and young people from 0 to 16 years old, such as foot test, vaccination, phonology, consultations with pediatricians and evaluation with a neuropediatrician physiotherapist.

Suffering at work has many consequences for the worker and, consequently, for organisational results, since both are intrinsically related. Thus, the study brings qualitative data that may help in the elaboration of strategies for the employees' QLW, thus opposing the taylorist vision at work.

\section{BIBLIOGRAPHICAL REVIEW}

\subsection{QUALITY OF LIFE AT WORK (QLW)}

Quality of Life at Work (QLW) has been a widespread theme in recent years due to the consequences that work has caused to workers. According to Ferreira, Alves and Tostes (2009), Quality of Life at Work can be regarded as an attempt to stimulate humanization at work and provide well-being to employees at work. In this case, it involves their greater participation in labor decisions and a fight against taylorist methods in order to deteriorate the employee's perception as a mere productive resource.

In continuity with this thought, Sampaio (2012) identifies QLW the satisfaction of individuals in the workplace. For the author, when the individual is satisfied at work, this will bring positive consequences for both the employee and the company, because there will be satisfaction in personal life and, therefore, a better performance.

Still in this sense, the humanist view is that QLW is associated with internal factors of the individual and in the context in which he is inserted, seeking satisfaction with the work. Studies indicate that the concern about QLW started in 1950 in England with the restructuring of work activities at Tavistock Institute. However, the Quality of Life at Work began to gain prominence after 1970 with the crisis in the methods of Taylor's Scientific Administration (FERREIRA; ALVES; TOSTES, 2009).

From the point of view of Limongi-França and Assisi (1995), even with this notoriety, in practice QLW programs have their difficulties, because companies adopt only a speech of implementation with pragmatism and short term investments. A large part of the QLW programs in organizations are limited to safety at work, which does not make sense, since a broader discussion is needed that encompasses other variables.

Based on these aspects, authors such as Albuquerque (2002) point out that QLW is an evolution of Total Quality. Thus, it is necessary to develop awareness and provide adequate working conditions taking into account the welfare of employees, i.e., it involves a broader context of quality with a management based on social responsibility.

Based on this information, it is clear that the employee needs encouragement and well being in his workplace, not just a better salary. It is also eminent to remember that the way the employee finds himself impacts positively or negatively on productivity within his workplace. 
According to Fernandes (1996), employees are increasingly questioning the work routine, the precarious conditions for carrying out activities and the lack of appreciation of skills. Thus, to corrupt these problems and provide a quality of life to the worker, there must be an effective QLW program so that the experience in the work environment is of pleasure.

\subsection{APPROACHES TO QUALITY OF LIFE AT WORK (QLW)}

Several authors approach Quality of Life at Work (QLW) and, according to Monaco and Guimarães (2000, p. 75), "Walton's model is the most extensive, contemplating processes of diagnosis of Quality of Life at Work, taking into account intra and extra company factors".

Walton's (1973) model has received attention as a way of emphasizing neglected ethical values at work due to the companies' constant search for profit optimization. The model consists of eight dimensions that influence QLW, among which are fair and adequate compensation, which involves the relationship between salary and labor factors, as well as the working condition, sometimes associated to physical conditions and aspects such as working hours.

The author also emphasizes that employees must use the skills in practice, where managers must guarantee them an opportunity for growth in the company. All employees must have good relations with colleagues for effective social integration and, in addition, constitutionalism must be present in organizations to avoid arbitrary decisions. The model goes beyond the sphere of work and highlights the balance between professional and personal life for a good quality of life. To this end, the company must adopt actions related to the social relevance of work, i.e., act on behalf of all employees in the workplace.

Another influential theoretical model is that of Hackman and Oldham (2010), which is divided into three stages, with the employee's working skills together with the significance of the task forming the first stage called "significant experience"; the information the employee has about the results of the tasks performed constitutes the second stage linked to "knowledge of results"; and, finally, the self-determination capacity of individuals constitutes the third stage characterized as "satisfaction with growth". After the presence of the three stages, the workers are motivated and, consequently, susceptible to perform a work with greater effectiveness.

In addition, the Nadler and Lawler model (1983), which presupposes the worker's participation in facing problems, forms of incentive to the employee, changes and improvements in working conditions, is highlighted. For the elaboration of an effective QLW program, the authors emphasize that planning with the development of projects at all hierarchical levels of the organization is necessary.

\section{METHODOLOGY}

As far as methodology is concerned, an exploratory qualitative approach research was carried out. According to Godoy (1995), in this type of approach the researcher goes into the field, collects data and analyses them. Thus, there is an appreciation of the content presented by the interviewees, where they can express their perceptions and representations.

Such an approach has an exploratory feature and is clarified in the course of the research from the integrated analysis of the people involved. In this way, all points of view are considered so that it is possible to understand the dynamics of the event. For that, qualitative research has some tools, such as interview and observation.

Based on these aspects, a structured interview was used for data collection in this study, which is characterized by having a questionnaire with pre-established questions as the basis for the interview (BONI; QUARESMA, 2005). The interview was carried out according to a sample made up of ten public professionals from a Maternal and Child Center in the municipality of Paraíba do Sul/RJ.

The questionnaire was composed of open-ended questions and divided into two parts. The first part allowed the identification of the respondent's profile (gender, age, marital status, education, time at work and training), while the second allowed the understanding of perceptions about Quality of Life at Work (QLW), the positive and negative factors of work and the suggestions of employees for improvements at work.

The observation was also used to record the occurrences of interest to the study. In this case, the observation was that of the participant type, which in turn presupposes the contact of the researcher to the group being interviewed (BONI; QUARESMA, 2005). 
The survey was carried out at the end of 2019 and in order to carry out the survey it was necessary to make a request to the maternity manager. The request was quickly accepted and therefore it was possible to do the work in the field. It should be noted that all interviewees responded promptly to the questions without any negligence or resistance.

\section{RESULTS}

To analyze in practice the perception of Quality of Life at Work (QLW) in a Mother and Child Center in the municipality of Paraíba do Sul/RJ, interviews were conducted with ten public employees. In view of this, it was found that the sample consisted of two men and eight women, these professionals being from the following positions: two nursing assistants, two trainees, one physiotherapist, two administrative agents and three nursing technicians.

The working hours of the employees interviewed at the public center range from three months to thirty years of organization and their workloads range from 30 to 40 hours per week. It is worth noting that of the employees who were interviewed, seven are in high school, two are in higher education and one is in the sixth period of higher education in nursing.

Among the respondents, two are married, six are single, one is widow and one is divorced. Regarding the number of children, four of these employees have children and six do not. The four employees who have children, one has only one child and the other three have two children each.

After the questions regarding the profile of the professionals, the aim was to inquire about what was the Quality of Life at Work (QLW) according to the perception of each employee. Thus, it was possible to obtain several answers, among which: having a good interpersonal relationship (good people at work, honest, empathetic, helpful, communicative and loyal team); a job with stability, dignified collections and a good salary; opportunities, progression and recognition; a clean and quiet environment where the professional has well-being in his service; and, finally, satisfaction, joy and incentive in the workplace. From these perceptions, it is important to emphasize that the majority cited aspects related to the teammate, with emphasis on good relationship and well-being at work.

The second question was in relation to the positive factors of QLW that exist in their work and, according to the perception of each one, the positive factors are: one reported that it is the fair productivity; one that it is the good work environment; one emphasized that it is the flexibility of the workload; one that is a clean place; one that is to have satisfactory results at the end of the day; and the others (five people) talked about aspects linked to the good relationship with their professional colleagues, such as pleasant people, ease in team work, friendship, respect and affection with their fellow men.

On the other hand, the third question was about the negative factors in the work that hinder QLW, which according to each respondent are: four reported being the material lack to perform the necessary daily functions making it hinder the performance of the professionals; three reported being the very extensive workload; one reported being human injustice; one emphasized being the lack of incentives and benefits; and highlighted the noise of the street.

Finally, it was asked what suggestions for improvement would give for a better quality of life at work. Thus, the interviewees mentioned that improvements could occur in the institution, which would be in relation to: reduction of workload; construction of a space for rest; more respect for employees; professional isonomy, coherence, efficiency, honesty, commitment and humanity; that superiors better evaluate the work before making decisions; better salaries; and more benefits of transportation and meal vouchers. It is important to point out that employees were able to give more than one suggestion.

\section{ANALYSIS OF THE RESULTS}

The results collected show the preponderance of women within the institution, since $80 \%$ of those interviewed are female, in addition to the fact that they have a larger age range and a longer working experience.

The Institution does not have a large number of young workers, and the smallest age group registered is 20 years old, which belongs to the female gender. This situation is not an isolated fact, since according to a survey conducted by the Brazilian Institute of Geography and Statistics (2018) shows that the unemployment rate among individuals up to 24 years of age was $27.2 \%$, compared to $11.6 \%$ of the average shown by the Brazilian market at 
the end of 2018. Another fact to be noted is that all those interviewed have completed high school, and only three of the ten have higher education, of these two women and one man, all with little time in the institution (4 months).

As for the Quality of Life at Work (QLW) analysis, it will be made based on determinant questions for the verification of the proposed theme in this work environment. Thus, it is observed that the perception of the interviewees about what QLW is is comprehensive, but most of them enter into a consensus that Quality of Life at Work is to have a good interpersonal relationship with the other employees of the institution and to have a wellbeing in the service, as it can be observed in the report of employee E1: "It is to have a good work team, because the health branch requires this reciprocity between all [...]."

Based on the studies acquired, it can be noted that the relationship between teammates is totally pleasant, since none of the interviewees complain about another employee, on the contrary, praise is frequent. Moreover, another positive point seen is that many of these workers are doing what they love, and this motivates them to continue this routine. In other words, the good interpersonal relationship that was cited by employees as a primordial element for Quality of Life at Work is being experienced by them in the work environment.

Therefore, it is observed that there is a social integration in the organization, which goes from being verified with what Walton (1973) employs in his model on Quality of Life at Work (QLW). In this way, individuals act in a harmonious way for the realization of services through good coexistence, which contributes to a favorable organizational climate.

However, there are some negative aspects that hinder the routine in the public center, the lack of work material being the biggest problem, a fact that other municipal networks in the city of Paraíba do Sul face. Through this, several problems arise, since being a Maternal Child Center, even the most basic materials are of total importance. In this case, the problem faced goes beyond harming the work of the employees, since it involves materials that would be used for the benefit of the population of the region.

In addition, another factor frequently mentioned is the high workload, which is a determining factor, since the lack of leisure time eventually comes to the fore, and the lack of it has a direct impact on the work and well-being of these people. According to Walton (1973), there are eight factors that affect QLW, one of which is extremely similar to the one evidenced in this research, which would be the condition at work, involving the working day dimensions. With this, the routine at work may become tiring and, consequently, cause wear and tear in the workers.

In this sense, the interviewees report ways of improvement for the Institution, which would be ways of improving the Quality of Life at Work (QLW), which concern the greater availability of materials for the accomplishment of the work activities and the reduction of the workload. As the interviewee E7 reported: "the dream of a 30-hour workload for nursing, because we are humans taking care of other human beings."

\section{CONCLUSION}

Through the study carried out, it was possible to deepen the knowledge about the public employees of a Mother and Child Center in the city of Paraíba do Sul, and through this, to identify the beneficial and harmful factors that the interviewees reported in relation to Quality of Life at Work.

After using a qualitative survey with the use of an interview and a questionnaire, it was possible to identify that the main factors that compromise the Quality of Life at Work of the employees of this Institution are the lack of basic resources to work and the workload, which end up making decent work impossible. However, these problems do not affect the relationship between workers, since the relationship between them is harmonious and considered the main positive factor in the unit.

The lack of public money invested in this institution is of extreme concern, especially since this is the main Mother and Child Center in the city, with approximately 45,000 inhabitants.

Moreover, the variables perceptions about QLW is a point to be emphasized, bearing in mind that, when we see from the interviewees, there is not only a primordial factor that will cause the Quality of Life at Work, but small factors that when connected form something bigger for the work environment. Thus, the consensus is that among these small factors should be included the interpersonal relationship and well-being at work.

Thus, it is concluded that with the transfer of funds being carried out by the city hall assiduously, the employees would have a better condition at work and the institution could become a better model of Mother and Child Center, in view of the harmonious relationship between them 
Quality of Life at Work in A Public Mother-Child Center in Southeastern Brazil

\section{SOURCES OF FUNDING}

This research received no specific grant from any funding agency in the public, commercial, or not-for-profit sectors.

\section{CONFLICT OF INTEREST}

The author have declared that no competing interests exist.

\section{ACKNOWLEDGMENT}

None.

\section{REFERENCES}

[1] AlBUQUERQUE, L. G. A gestão estratégica de pessoas. São Paulo: Editora Gente, 2002

[2] BONI, V.; QUARESMA, J. L. Aprendendo a Entrevistar: como fazer entrevistas em Ciências Sociais. Florianópolis: Revista Em Tese, v. 2, n. 1, p. 68-80, 2005.

[3] CUT. IBGE: Número de desempregados no país cresce entre os mais jovens. Diposnível em: $<$ https://www.cut.org.br/noticias/numero-de-desempregados-no-pais-cresce-entre-os-mais-jovens6e1a\#: :text=No\%20trimestre\%20encerrado\%20em\%20dezembro,Geografia\%20e\%20Estat\%C3\%ADstic a\%20(IBGE) >. Acesso em: 21 outubro 2019.

[4] FERNANDES, E. Qualidade de vida no trabalho: como medir para melhorar. 2 ed. Salvador: Casa da qualidade, 1996.

[5] FERREIRA, M. C.; ALVES, L.; TOSTES, N. Gestão de qualidade de vida no trabalho (QVT) no serviço público federal: o descompasso entre problemas e práticas gerenciais. Brasília: Psicologia - Teoria e Pesquisa, v. 25, n. 3, p. 319-327, 2009

[6] GODOY, A. S. Pesquisa qualitativa: Tipos Fundamentais. São Paulo: Revista de Administração de Empresas, v. 35, n. 3, p. 20-29, 1995.

[7] HACKMAN, J. R.; OLDHAM, G. R. Future of job redesign research. Journal of organizational behavior, 31, 463479. DOI: 10.1002/job, 2010.

[8] IBGE. População no último censo. 2018. Disponível em: <https://cidades.ibge.gov.br/brasil/rj/paraiba-dosul/panorama>. Acesso em: 21 outubro 2019.

[9] LIMONGI-FRANÇA, A. C.; ASSIS M. P. Stress projetos de qualidade de vida no trabalho:caminhos percorridos e desafios. São Paulo: ERA light, mar/abr. v.2, n.2. p.26-32, 1995.

[10] MÔNACO, F. GUIMARÃES, V. N. Gestão da qualidade total e de vida no trabalho: o caso da gerência da administração dos correios. São Paulo: RAC, v.4, n.3, set./dez., p.67-68, 2000.

[11] MACHADO, L. S. F. et. al. Agravos a saúde referidos pelos trabalhadores de enfermagem em um hospital público na Bahia. Revista brasileira de enfermagem, v. 67, n. 5, p. 684-91, out-2014.

[12] NADLER, D. A.; LAWLER, E. E. Quality of work life: perspectives and directions. Amsterdam: Organizational Dynamics, v. 11, n. 3, p. 20-30, 1983.

[13] SAMPAIO, J. R. Organizações e Trabalho. São Paulo: Revista Psicologia, 12(1), jan-abr, p. 121-136, 2012.

[14] WALTON, R. E. Quality of working of life: What is it?. Cambridge: Slow Management Review, v. 15, n. 1, p. 11$21,1973$. 